\title{
Transition from the Developmental State: The Deliberative Policy Process of Civil Service Pension Reform in Korea*
}

\author{
Huck-ju Kwon** and Eunju Kim ${ }^{* * *}$
}

\begin{abstract}
This paper examines three recent efforts to reform Korea's Civil Service Pension Program, in order to trace the changing policy process in Korea, where the policy regime of the developmental state used to be predominant. It has been argued that the government no longer has overwhelming influence over the policy-making process, while social actors are not able to compromise on social issues. This paper aims to test the hypotheses of the decline of government influence and the inability to reach social compromise, focusing on stakeholders' interactions at the micro level. It argues that a new deliberative policy process has emerged that engages a range of stakeholders, such as trade unions and policy experts, and in which different government ministries compete against each other. The paradox of the new policy process is that despite its deliberative nature, the government's strategic influence continues to be strong.
\end{abstract}

Keywords: civil service pension, policy making, pension reform, deliberative policy process

* The initial motif of this article came from a study of the financing of welfare organized by UNRISD(United Nations Research Institute for Social Development) in 2007. Further research and interviews were carried out as a part of the activities of the Global Research Network on Social Protection in East Asia, which is funded by the National Research Foundation (NRF-2010-220-B00027).

** Huck-ju Kwon is a professor in the Graduate School of Public Administration, Seoul National University, Korea. His recent publications include Transforming the Developmental Welfare State in East Asia (Palgrave, 2005), The Korean State and Social Policy (Oxford University Press, 2011), and a number of journal articles, including "Policy Learning and Transfer: The Experience of the Developmental State in East Asia" (Policy and Politics, 2009) and "Introduction: Social Policy and Economic Development in Late Industrialisers" (International Journal of Social Welfare, 2009). E-mail: hkwon4@ snu.ac.kr.

*** Eunju Kim is a Ph.D. candidate in the Graduate School of Public Administration, Seoul National University. E-mail: joanne@snu.ac.kr.

Manuscript received October 24, 2011; out for review October 26, 2011; review completed November 22, 2011; accepted December 1, 2011.

The Korean Journal of Policy Studies, Vol. 26, No. 3 (2011), pp. 91-111.

(C) 2011 by the GSPA, Seoul National University 


\section{INTRODUCTION}

This paper analyses the evolution of the policy process in Korea using the case of the reforms of the Civil Service Pension Program. Existing literature points out that the government plays a dominant role in policy making, using social policy as a strategic tool for economic development (Holliday, 2000; Kwon, 2003). Following the theory of the developmental state (Haggard, 1988; Johnson, 1999), it characterizes the process of social policy decision making in terms of the government's domination: a small circle of top decision makers and bureaucrats make decisions while social actors are given little opportunity to voice their opinions.

As democracy has been consolidated in Korea, political actors are now able to voice their interest and often confront the government when their interest is thought to be compromised by government policy. There is decreasing room for the bureaucracy to pursue strategic policy objectives that might compromise the interests of certain sections of society. In social policy making, actors other than the government have also begun to play an important part. In his comparative study of public pension reform in the late 1990s, Choi (2008) argues that businesses exerted a strong influence on the reform of social security. Song and Hong (2006) highlight the role of civil society actors and trade union members in government commissions under the Kim Dae-jung administration, which turned out to be highly influential in the wake of the economic crisis in 1997. In a nutshell, a growing body of scholarship shows that the government can no longer dominate the policy process as it used to (see Wong, 2005).

In contrast, there is also a strong argument that the developmental state is still one of the viable alternatives to a neoliberal policy regime (see Hayasi, 2010). The government still plays a significant, if not dominant, role in public policy. Weiss (2000) argues that the developmental state is adapting and innovating, not disappearing. With such competing views of the government's role in policy making, can the hypothesis of the decline of government influence in the policy process be ascertained? Has a new modus operandi of policy process emerged in the context of democracy, particularly a deliberative policy process?

In parallel with the hypothesis of the decline of government influence, there has also been pessimism about the possibility that Korean politics goes beyond an electoral democracy. In particular, the deliberative policy process has been tried in Korea, but its feasibility is doubted. Social actors are not prepared to engage in policy deliberation with reason and persuasion. Most notably, the tripartite committee (comprised of labor, management and government sectors), which played a crucial role in forming a social consensus for reform during the Asian economic crisis, soon became irrelevant due to the inability of social stakeholders to make compromises (Baccaro \& Lim, 
2007). It could not continue discussions, losing its relevance in policy making after the Korean Confederation of Trade Unions walked out of it in 1999. Additional evidence for this pessimism was the candlelight manifestation at the beginning of Lee Myungbak's presidential tenure in 2008. Massive street demonstrations against the government's trade policy signified a lack of ability on the part of policy stakeholders, the government, and social stakeholders alike to engage in a deliberative process.

This paper sets out as a hypothesis the decline of the role of the government and the inability of policy actors to achieve social compromise. In doing so, it takes the case of the civil service pension reform, since this lies at the core of the welfare state in Korea. In contrast to existing literature that tends to analyze at a macro level, the authors will analyze the evolution of the role of the government in the process of social policy making at the micro level, by tracing the deliberative policy process set out for the reform of the Civil Service Pension Program. The authors will argue that government influence in the policy process remained strong: the government was able to exert its influence in a deliberative setting so that the Civil Service Pension Program stayed at the core of the welfare state in Korea.

During the decade beginning in 2000, there were three attempts at civil service pension reform in Korea. The first and third attempts were carried through, but the second failed. Kim Dae-jung's government carried out the first reform in 2000 in order to consolidate the financing of civil service pensions. The reform raised the level of contribution and allowed the government to underwrite the solvency of the program. The second attempt, in 2006, by the Roh Moo-hyun government, failed to undertake structural reform of the Civil Service Pension Program; but the third, under the government of Lee Myung-bak, managed to carry it through in 2009. Through these three different reform efforts, one can examine the way in which policy making has evolved in Korea and the emerging pattern of the policy process.

In order to capture these changes in the policy process, it will be necessary to set out a framework for analyzing policy making that can deal with different patterns: the policy process under the developmental state and the deliberative process after democratic consolidation. The authors will shed light on three dimensions of the policy process: first, policy priorities or goals; second, the range of participation by policy actors; and third, institutional networks and the mode of coordination and influence among policy actors.

Weiss's (2000) discussion on the developmental state provides a reference point for comparison. She describes the developmental state as, first, setting economic growth as a priority. Second, the main actors in decision making are top policy makers and bureaucrats, especially in the economic ministries, whose policy priority is economic growth, while other actors tend to be decision receivers. Third, this network of actors 
Table 1. Analytical Framew ork of the Policy Process

\begin{tabular}{l|l|l}
\hline & Policy process of the developmental state & Deliberative policy process \\
\hline Policy priority & Economic growth as an overarching objective & M ultiple and competing policy goals \\
\hline Policy actors & $\begin{array}{l}\text { The state as the only decision maker and others } \\
\text { as decision takers }\end{array}$ & $\begin{array}{l}\text { A wide range of policy actors and } \\
\text { participating stakeholders }\end{array}$ \\
\hline $\begin{array}{l}\text { Institutional mode } \\
\text { of coordination }\end{array}$ & $\begin{array}{l}\text { Hierarchical institutional arrangements with } \\
\text { a single center } \\
\text { Decision makers and decision receivers }\end{array}$ & $\begin{array}{l}\text { Deliberative political process involving policy } \\
\text { actors' interaction } \\
\text { Persuasion and compromise }\end{array}$ \\
\hline
\end{tabular}

is maintained through hierarchical institutional arrangements with a single center, in which power is highly concentrated in the hands of the president and his close lieutenants. The policy process that Weiss describes is typical of the developmental state in its traditional form.

Against the backdrop of the developmental state, the authors will trace the evolution of the policy process over the last decade, using the case of the civil service pension reforms. As shown in table 1, the paper will first examine whether there are now multiple and competing goals in contrast to economic growth as the overarching goal in the past. Second, it will analyze the range of participation and examine whether policy actors exercise equal influence. Third, it will examine how persuasion and compromise are made in the deliberative process. In this paper, we define the deliberative policy process as a forum with institutional or semi-institutional structure in which stakeholders or actors are able to advance their arguments with evidence. In the deliberative forum, the participants will have equal opportunity to voice their arguments and exercise bargaining power. It aims to make deliberative decisions to compromise on arguments and then persuade stakeholders in institutionalized settings. ${ }^{1}$

\section{THE STRUCTURE OF THE PUBLIC PENSION SYSTEM}

In order to analyze the three reforms of the civil service pension program that took place over the course of the last decade, it is necessary to locate Korea's public pension systems in a comparative map of the diverse existing systems of public pensions,

1. Based on this definition of deliberative process, we consider the voice of various societal actors to be reflected through policy experts or labor unions in the institutionalized setting. In the theory of deliberative democracy, the "public sphere" is an essential part of the process. However, for the sake of concise analysis, we concentrated on the actors who participated in the institutionalized setting. 
Figure 1. Three Ideal Types of Public Pension System

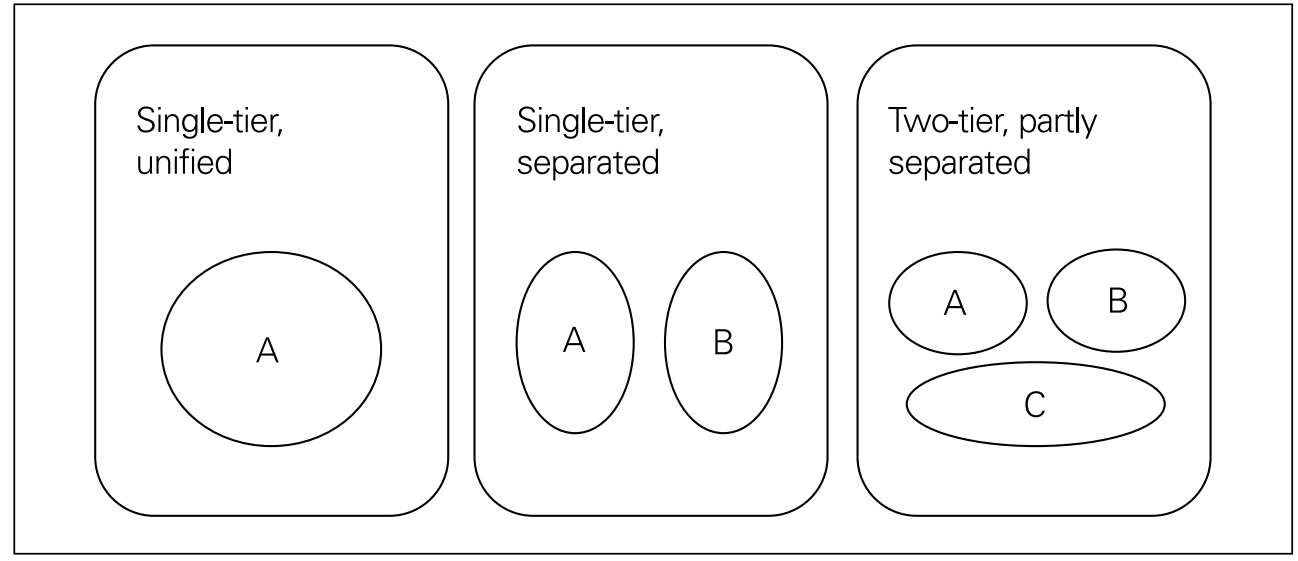

A: National pension program for all citizens

$\mathrm{B}$ : Civil service pension program

C: National Basic pension program

such as multipolar and multitier systems (James, 1997). Public pension programs can be divided into three ideal or typical systems, as presented in figure 1.2 The first one is a single-tier unified system, in which the public pension program covers all citizens, whether they are employees in the private sector or civil servants. The second one is the single-tier separated system, in which privately employed citizens and members of the civil service join separate pension programs, the latter do not necessarily having configurations in terms of the level of contributions and pension payments. The third one is a two-tier, partly separated system in which all citizens are covered by a national basic pension program, while employees in the private and public sectors have separate second-tier pension programs.

The Korean public pension system belongs to the second type of system-which is also in place in some countries in Europe, such as France and Germany-with the Civil Service Pension Program for members of the civil service and the National Pension Scheme for the public at large. The pension systems in Sweden and the UK can be categorized as belonging to the third type of system.

In the second ideal type, pension programs for the civil service take a prominent position for two reasons: they are different from pensions for the general public, and

2. In figure 1, private pension schemes are not included. If they were, there would be another tier on top of the system portrayed in this figure. As private pension schemes normally operate in the market system with many competing insurers, they could be shown as a number of small circles at the top of each system. 
the system, as a result, privileges the members of the civil service. Though not necessarily true in every case, civil service pensions in this type tend to be more generous than those for citizens in private employment. Public pension systems of the second type tend to exist in countries where the government seeks to secure the loyalty of the bureaucracy with generous pension programs (Meny, 1990).

The next section of this paper traces the evolution of the Civil Service Pension Program within the context of the developmental state. The paper then analyses the reform's policy process in light of the three dimensions of this policy process (policy priority, range of participation, and institutional mode of coordination).

\section{THE DEVELOPMENTAL STATE AND KOREA'S CIVIL SERVICE PENSION PROGRAM}

The Civil Service Pension Program in Korea was introduced in 1960 by the Chang Myun government (1960-1961) just before it embarked on an ambitious five-year economic development plan. These state-led plans were put into operation in many developing countries in the 1960s. In order to implement its plan, the Chang government tried to attract young university graduates into the government. The Civil Service Pension Program was one of the policy instruments in this effort. However, the Chang government did not have time to carry out the plan due to its sudden overthrow by a military coup d'etat led by Park Chung-hee in 1961.

Though specific details changed, the Park government did maintain the previous government's basic rationale for economic development policy and embarked on the First Five-Year Economic Development Plan in 1962. The Park government continued to carry out economic development policy with successive economic plans while the policy emphasis shifted from import-substitution industrialization to export-led development in the mid-1960s. In the process of economic development, the state and its bureaucracy played a pivotal role, reflecting properly the notion of the developmental state (Adelman, 1997; Kohli, 2004). The government worked in a highly coherent manner from the top to the bottom, as the state machine was under the president's direct control, using the Office of the Blue House and the Korean Central Intelligence Agency as instruments. In a nutshell, it demonstrated an ideal typical of the developmental state.

In the highly organized and disciplined structure of the developmental state, there lies a merit-based bureaucratic system that is a driving force for development. Aside from its organization, the bureaucracy's openness to all social classes offers an additional strength. Young talent is recruited from the entire population-as opposed to a particular social class with political influence-through entrance examinations. Given 
that the education system was open to most young people, those from poorer backgrounds could - if they worked hard-compete academically with those who were better off because of the absence of social barriers (Yoo, 1966).

The civil service was not highly paid compared to the private sector, in terms of remuneration. The average level of pay for bureaucrats even became lower than that of the private sector once the Korean economy started to record impressive growth in the late 1960s and 1970s (Ro, 1981). With defense expenditure accounting for 30-40 percent of the government budget after the Korean War, and another 20 percent for repayment of loans and interest, the government did not have much room to provide high remuneration to the bureaucrats (Ro, 1981).

How, then, was the morale and discipline of the bureaucracy maintained in spite of the low pay levels? The immediate answer would be the strong commitment of the bureaucrats to national development (Ro, 1981). Additionally, there were other economic incentives for bureaucrats. Unlike their counterparts in the private sector, the bureaucrats' jobs were secure almost for their entire working career, unless they committed serious wrongdoing. In the early 1960s, higher-salary jobs in the private sector were limited, although new opportunities emerged once economic growth took off in the mid-1960s. On top of job security, bureaucrats could look forward to a civil service pension, while citizens in private employment waited until 1988 for the National Pension Scheme to be introduced.

Neither job security nor civil service pensions required immediate fiscal spending. Starting in the 1960s, the administrations made pension promises to the civil service while providing low salary levels, while future administrations would need to bear the expense of the pension program when it matured. In a way, the Korean government borrowed money from the future to ensure bureaucrats' commitment through civil service pensions.

Pensions were generous because they were based on the salary of the last year of employment. The aim of this measure was to give incentives for civil servants to work toward promotion and consequently higher salaries in the last years of their careers. This formula was changed in 1995. The revised formula used the average salary received in the last three years of service in order to determine the pension amount, as shown in figure 2.

Figure 2. Formula for Civil Service Pensions

Pension $=(A W \times 0.5)+(A W \times 0.02 n)$

where AW is the average of the level of the last three years' salaries and $n$ is the number of years of service over 20 years. 
Table 2. Number of Pensioners in the Civil Service Pension Program

\begin{tabular}{c|c|c|c}
\hline & Working civil servants & Pensionersa) & Pension-dependency ratiob) \\
\hline 1982 & 667,754 & 3,742 & 0.6 \\
\hline 1985 & 696,951 & 9,078 & 1.3 \\
\hline 1990 & 843,262 & 25,396 & 3.0 \\
\hline 1995 & 957,882 & 56,343 & 5.8 \\
\hline 1998 & 952,154 & 89,332 & 9.3 \\
\hline 1999 & 913,891 & 128,940 & 14.0 \\
\hline 2000 & 909,155 & 150,463 & 16.5 \\
\hline 2005 & 986,339 & 218,006 & 21.9 \\
\hline 2007 & $1,021,771$ & 229,157 & 24.7 \\
\hline
\end{tabular}

a) Including survivors; b) pension-dependency ratio = (pensioners/contributors) $\times 100$.

Source: Government Employees Pension Service, 2007.

The Civil Service Pension Program did not have financial difficulties until the late 1990s. This is hardly surprising because the program required members of the civil service to contribute for at least 20 years before they could claim their pensions. Even after retired civil servants began to claim their pensions, the number of pensioners remained small. The pension-dependency ratio-that is, the proportion of pensioners to working civil servants-remained less than 5 percent until 1994 (see table 2). For instance, in 1990, there were around 25,000 retired civil servants and their survivors receiving pensions; this accounts for a dependency ratio of 3.0 percent.

The reasons the pension-dependency ratio was low were manifold. First, the life expectancy of the cohort who joined in the civil service in the 1960s was not long. Longevity after retirement must have been short, although the life expectancy of civil servants has normally been longer than that of privately employed citizens. Consequently, the number of pensioners did not increase rapidly. Second, fewer than half the retired civil servants met the requirement of a minimum of 20 years of contributions. For example, in 1994, 36,875 civil servants retired, but only 35.7 percent were eligible for a full pension. Civil servants who did not meet the 20 -year requirement received a lump-sum payment. ${ }^{3}$ Third, among those eligible for pensions, only 30 percent chose to receive a pension, since they could also opt for a lump-sum payment.

3. Lump-sum payments for civil servants with less than five years of service were calculated as follows: pensionable salary of the last month in service $\times 1.2$. Lump-sum payments for those with more than five years of service were calculated as follows: pensionable salary of the last month in service $\times$ years in service $\times 1.5+$ (pensionable salary of the last month in service $\times$ years in service over five years $\times 0.01$ ). 
Table 3. Early Retirements in the Civil Service

\begin{tabular}{c|c|c|c|c|c|c|c}
\hline Year & 1996 & 1997 & 1998 & 1999 & 2000 & 2001 & 2002 \\
\hline Early retirements & 3,482 & 2,875 & 14,816 & 35,409 & 20,342 & 5,387 & 3,231 \\
\hline
\end{tabular}

Source: Government Employees Pension Service, 2005.

These trends changed as the social structure in Korea changed, following the impressive economic development of the 1970s and 1980s. Life expectancy rose quickly, going beyond 70 years; the number of civil service retirees who met the minimum requirement for a pension also increased; and more and more retirees began to choose to receive pensions. As table 2 shows, in 1995 the pension-dependency ratio increased to 5.8. The sudden increase in the number of pensioners in 1999 was not, however, due to those long-term structural changes. As the Korean economy was struck by the Asian economic crisis in 1997-1998, structural reforms were carried out in the economy. In 1998-1999 the government offered early retirement to civil servants as part of a wider policy of reducing the number of public sector employees (see table 3). It was also an effort to create vacancies for young graduates, a large number of whom feared they would be unemployed. In particular, the government carried out a compulsory retirement in public schools to force senior teachers to retire during this period.

\section{REFORM OF THE CIVIL SERVICE PENSION PROGRAM IN 2000}

The sudden increase in the number of pensioners in the late 1990s led to a sharp rise in pension expenditure, as shown in figure 3. It exceeded the revenue in 1998, which led to a deficit in the overall finances of the Civil Service Pension Program. In response, the government decided to reform the program in 1999 and complete the process in 2000.

The initiation of the reform process came from the Ministry of Government Administration and Home Affairs, which was responsible for the Civil Service Pension Program. In the wake of the program's financial deficit, the ministry commissioned the Korea Development Institute (KDI), a government think tank, to research the issue and propose policy options. In the end, the ministry set the main agenda for reform, which was basically threefold: first, to increase the level of contributions; second, to set the pensionable age at 60 , which was to be incrementally implemented by 2021 ; and, last, to change the basis of pensionable salary from the last year of service to the last three years of service (Korea Development Institute 1999).

The mainstay of the reform was to raise the contribution from 7.5 percent to 8.5 
Figure 3. Financial Situation of the Civil Service Pension Program

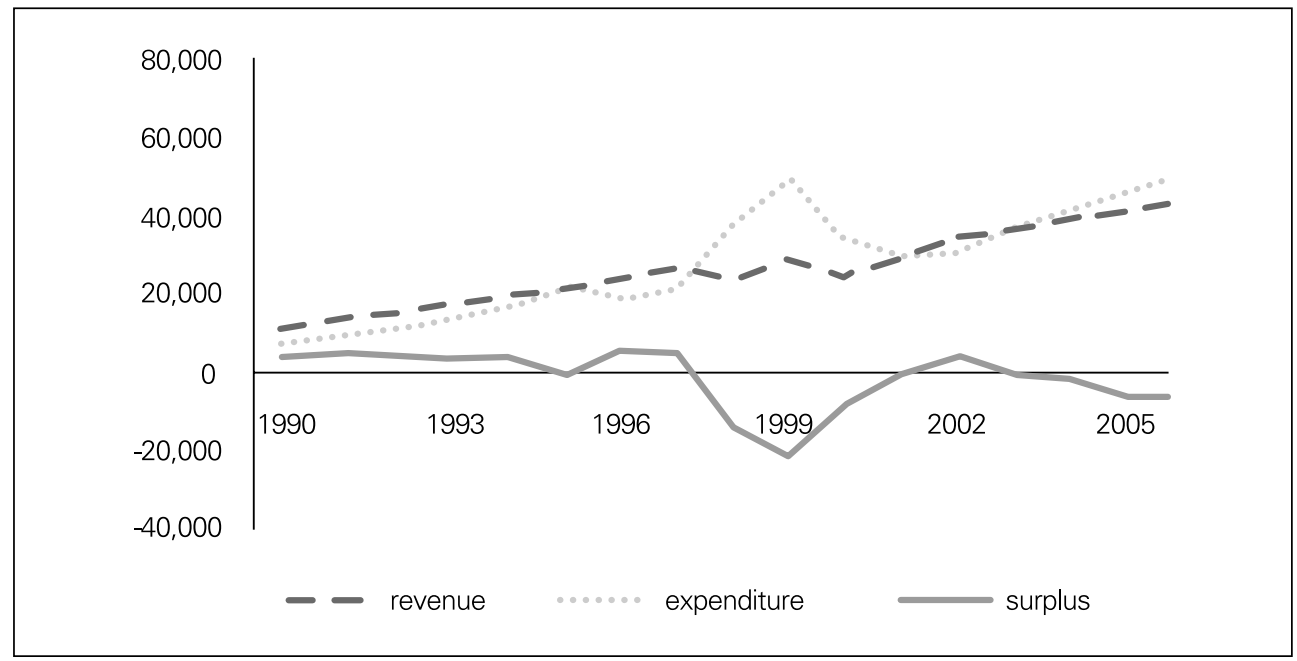

Source: Kim \& Kim, 2002. (Unit:100 million Korean W on)

percent of the main salary (excluding other payments, such as overtime and hazard pay). Nevertheless, it was not enough to put the financing of the Civil Service Pension Program at a sustainable level. The government decided to finance future deficits as an ultimate guarantee of the pension program.

In order to push through the reform, the government set up a task force within the Ministry of Government Administration and Home Affairs in July 2000. The task force arranged a series of consultations during the latter half of that year. Public employees of the central and local government voiced dissatisfaction and anger with the reform. They opposed the raise in the level of contributions and pensionable age. Most importantly, many civil service employees saw the reform as breaking a promise. Civil service unions, which had not yet gained full legal status, were against an increase in contributions but were not able to exercise any significant influence on the reform process.

In contrast, most policy experts and members of civil society organizations who were invited to consultation meetings were, in general, in favor of the reform, but were against the government underwriting the pension program. Commentators in the public media took positions similar to those of policy experts. In other words, objections to the reform were based on different reasons. These different positions put enormous pressure on government employees to accept the government's reform proposal.

Despite the opposition, the government went through the reform process without much difficulty. This was because the stakeholders did not develop effective strategies, 
although their participation in policy making had been on the rise since the economic crisis of 1997. While the government maintained its traditional strength in terms of agenda setting and decision making, the influence of other policy stakeholders-such as civil servant unions, policy experts, and civil society organizations-was limited, even though they came to play a part in the decision making. The government was also not prepared to engage fully with other policy stakeholders in a process of policy compromise.

For instance, the proposal for reform drafted by the KDI was discussed within the government. KDI was the only actor with significant influence who was deeply involved in shaping the reform. For the other actors, the government convened a public hearing in which the reform proposal was presented; but the stakeholders saw it as a mere formality for the government to proceed with the reform. The civil service unions were not effective in voicing their objections to the reform, and although other stakeholders, such as pensioners, voiced their opposition, their voices were too weak to change the course of reform.

In a nutshell, the government dominated the decision-making process in the 2000 reform, in a manner typical of the developmental state. It is fair to say that participation in the policy-making process was selective, in the sense that government officials and a small number of policy experts were involved. The reform bill was submitted to the National Assembly and passed in December 2000.

\section{THE FAILED REFORM EFFORT OF 2006-2007: THE ROH GOVERNMENT}

Theoretically, with the passing of the reform bill in 2000, the Civil Service Pension Program's finances should have been sustainable as long as the government's overall fiscal condition was sound, as a government subvention would cover any deficit. After the reform of 2000, the financial situation of the Civil Service Pension Program did improve - even before the government subvention, as shown in figure 3-due to a rise in the level of contributions. In practice, however, this solution was only temporary, and the deficit manifested itself again from 2003 onward. There was also increasing criticism from the public about the government subvention for the program. This opened a window for policy entrepreneurs to pursue another reform of the Civil Service Pension Program (Kingdon, 1984).

In 2005, the Minister of Health and Welfare triggered renewed debate on the reform of the Civil Service Pension Program. The minister intended to reform the National Pension Scheme in order to make it financially sustainable, since it was 
expected that the accumulated pension fund would be depleted in 2045 (Lee, 2007). For the minister, it would be much easier to carry out this reform in tandem with reform of the Civil Service Pension Program. However, this was not a high priority on the agenda of the Ministry of Government Administration and Home Affairs, which was responsible for the Civil Service Pension Program.

In circumstances in which different ministries were involved and took different positions, senior policy makers from the ministries normally met to find mutually acceptable solutions - an approach one could expect under the policy regime of the developmental state. In this instance, however, the Minister of Health and Welfare publicly criticized the Ministry of Government Administration and Home Affairs' inaction and emphasized the urgent need for reform. An open quarrel between ministers was a rare incident, but it now occurred, and the Minister of Government Administration and Home Affairs became upset about another minister's encroachment on his portfolio (Dong A Daily, 16 February 2006). From the viewpoint of agenda setting, this was a clear contrast to the previous experience under the developmental state. The issue of reform was raised by "outsiders" instead of by the ministry responsible for the civil service pension - the Ministry of Government Administration and Home Affairs. More importantly, the open disagreement on the issue between government ministers showed that the way in which government decisions were made had changed significantly.

In contrast to the 2000 reform, there was effective participation by other stakeholders in the 2006-2007 debate. Some policy experts argued that the Civil Service Pension Program should be reformed in line with the National Pension Scheme. Others suggested that it should be abolished because it was unfair that there was a separate, more generous public pension program for the civil service (Kim, 2005). It was argued that if the Civil Service Pension Program continued to exist, contributions and benefits should be the same as those in the National Pension Scheme. Aside from policy experts, major Korean newspapers such as Joongang Daily and Chosun Daily carried editorials urging the government to reform the Civil Service Pension Program. In brief, the argument proposed a structural change to the Korean public pension system from a single-tier separated system to a single-tier unified one, as shown in figure 1.

Under pressure, the newly appointed Minister of Government Administration and Home Affairs established a Committee on the Reform of the Civil Service Pension Program in July 2006. This committee comprised 21 members, ranging from senior government officials from different ministries to university professors, civil service union members, and pensioners under the program.

Initially, only the minor civil service unions were represented on the committee, since some major unions did not accept the invitation and others, such as the Korean 
Government Employees' Union (KGEU), were not invited because they did not have legal status as unions. The committee began to discuss four basic options initially prepared by the KDI, an outcome of the study commissioned by the Ministry of Government Administration and Home Affairs. The committee had 11 plenary meetings and 16 subcommittee meetings between July 2006 and April 2007. During this time, the major civil service unions staged a number of public demonstrations against the reform, while some policy experts demanded more far-reaching reform.

In April 2007, the committee presented its report to the Minister of Government Administration and Home Affairs. It proposed different plans for current civil employees and future recruits. For those already in service, the level of contributions would increase by 15 percent for the first five years, and then increase by another 13 percent for the second five years. Benefits would also be cut through the change of indexation: from income to consumer price index. Those who joined the service after the reform would contribute the same amount and receive the same level of pensions as those in the National Pension Scheme. The proposal also called for an increase in the level of the lump-sum payment-which was 30-40 percent of that offered in the private sectorto the same level as that in the private sector. For new members, a Thrift Saving Plan would be introduced, to which the government and civil service members would each pay 2.5 percent of their salary.

The proposal was opposed by all stakeholders related to the Civil Service Pension Program. Objections, however, were based on different rationales and therefore pointed in opposite directions. First, the major civil service unions opposed the reform proposal because it would increase the level of contributions. Second, some policy experts outside the government, as well as opinion leaders, opposed it because it did not reduce the overall level of pensions significantly, if lump-sum payments were included. Third, the Ministry of Finance and Economy (now the Ministry of Strategy and Finance) opposed it because it did not reduce the deficit, which meant that the level of government subvention to the program would remain the same. This was because higher lump-sum payments for civil service members would cost the public more money than the savings made by a reduction in pensions. Amid these strong objections, the Minister of Government Administration and Home Affairs did not accept the report and asked the committee to convene again for reconsideration.

The second attempt to reform civil service pensions, which ended in failure, showed a very different policy process from that of the developmental state. First, although the government took the initiative for reform, there were open disagreements between government ministries over this reform, notably between the Ministry of Government Administration and Home Affairs and the Ministry of Health and Welfare. It was, however, the Ministry of Finance and Economy that vetoed the reform proposal. 
Instead of uniting for economic growth as in the past, the government ministries pursued different policy goals. The Ministry of Finance and Economy prioritized longterm financial sustainability; the Ministry of Health and Welfare urged consolidation of two separate pension schemes in order to secure financial resources; and the Ministry of Government and Home Affairs, which was in charge of personnel, recognized civil service pensions as an important tool for recruiting talented government officials. In this regard, the policy goals of the respective ministries were bound to collide.

Second, many stakeholders were able to voice their arguments and, to a certain extent, exert their influence over the policy process. Third, a deliberative framework was introduced in which nongovernmental actors such as policy experts, members of civil society groups, and journalists could participate in the deliberative process. Although there were civil service employees, the major civil service unions were notable absentees in the deliberative framework due to their lack of legal status. Despite all these new characteristics, the second reform episode did not succeed.

\section{REFORM IN 2009: THE LEE GOVERNMENT}

The Committee on the Reform of the Civil Service Pension Program started its second term in July 2007. It had a number of meetings during which subcommittees considered various options. Because of the presidential election set for the end of 2007, there was uncertainty about the direction of reform, and no significant progress was made. In 2008, when the government of Lee Myung-bak (2008-present) was inaugurated, there were great expectations for a whole range of changes in policy orientation-including the reform of the Civil Service Pension Program-because the power had shifted from Roh Moo-hyun's center-left government to the center-right government of Lee Myung-bak.

In June 2008, the newly named Minister of Public Administration and Security (in what was formerly the Ministry of Government Administration and Home Affairs) appointed new members to the reform committee, including six members of major civil service unions. By this time, the civil service union KGEU had obtained legal status. Together with KGEU, the Korean Teachers and Education Workers' Union decided to join the committee. The unions decided to join because they saw that reform of the Civil Service Pension Program was unavoidable. Given this situation, it was better to participate in the committee and make their case during the drafting of the reform proposal. From the point of view of the ministry, it would be better to include union members who had previously opposed the reform in the committee, so that they could make compromises at the committee stage rather than choose direct 
political confrontation after the committee had made its decisions.

The first major issue on the agenda for reform was the question of whether the Civil Service Pension Program would be kept separate or be integrated into the National Pension Scheme - that is, the structural reform of the public pension system. The crux of the matter was whether the Civil Service Pension Program was an essential part of the civil service, in which case it should remain separate. This also led to the question of whether jobs in the civil service were inherently different from those in the private sector. Some economists in the committee saw no difference between public- and private-sector jobs and did not agree that there should be a separate public pension program for the civil service, but argued that it should be part of the National Pension Scheme. In contrast, some committee members, including experts in public administration and civil service unions, argued that the civil service pension should be maintained in order to compensate for the economic and political restrictions, such as limited rights to union activities, imposed on civil service members (Kwon \& Kwak, 2006). It was also argued that the level of remuneration in the civil service was lower than that of the private sector (Kim, 2004). Senior officials beyond a certain rank were not allowed-for a minimum of three years after retirement-to work in industries related to their previous work. In brief, they saw that the civil service pension was a crucial policy instrument of personnel management.

In a wider context, a section of society believed that the Civil Service Pension Program was one of the legacies of the developmental state. Another significant section of society thought that the state should continue to play a strategic role in the future, but in a different way. This debate mirrored a general debate — taking place in other societieson the state and market. After long discussions, however, there emerged a consensus in the committee that civil service pensions should be kept separate from the National Pension Scheme. Underlying this consensus was a factor related to the institutional path dependency of the public pension system in Korea. While the Civil Service Pension Program matured fully within 55 years of its implementation, and created a financial deficit, the National Pension Scheme had just begun to provide full pensions in 2008, accumulating a large amount of funds. Because of this difference in their institutional paths, it would be technically difficult, if not impossible, to merge these two schemes.

The second issue was how to stabilize the financing of the pension program. In order to discuss technical issues, the committee established a subcommittee that consisted of pension experts and union members. It decided to raise the rate of contributions by 8.6 percent immediately after the bill was passed, and up to 27 percent for the first five years. This was twice as high as the rate recommended by the committee in its first published report. Since the union members in the subcommittee were willing to accept the increase in contributions, it was easily agreed upon. This concession 
Figure 4. New Formulas for Civil Service Pensions

Pension $=$ AW $\times 1.9$ or Pension $=$ AW $\times 1.8$

where AW is the average of the level of salaries for the whole period of employment.

from the unions came from their position that the level of the pensions for current working members should be maintained. They were adamant about this. If this demand was accepted, the unions were also willing to accept consumer price indexation instead of income indexation. The pension formula turned out to be the toughest issue to agree upon. In particular, there was a clear gap between pension experts and unions with regard to the multiplier in the formula. Unions wanted to set the multiplier at 1.9, while some policy experts wanted it to be 1.8 (see figure 4).

The subcommittee was not able to agree unanimously on this issue, although they did agree on other topics, such as the incremental shift to consumer price index in terms of indexation, the reduction of survivors' benefits from 70 percent to 60 percent of the full pension, and the introduction of a maximum pension amount. The committee, in a plenary session held in September 2008, reviewed the proposal by the subcommittee and voted to set the multiplier at 1.9 , although a minority continued to insist that this was too high. The committee submitted its second report to the Minister of Public Administration and Security together with the minority opinion.

The proposal was sent to the National Assembly, in which the governing party held a majority. Nevertheless, the bill was not passed easily, since the opposition party was able to block it in the National Assembly's Standing Committee on Public Administration and Security. In addition, there was a political standoff between the governing and opposition parties after the sudden death of former President Roh in 2009. The opposition party members were able to add to a new clause in the reform bill that would set a ceiling on pensions and would reduce the pensions of long-serving high officials such as judges and prosecutors. With this compromise, the bill was passed by the National Assembly in December 2009. All in all, the bill would not change the basic structure of the public pension system, in the sense that the Civil Service Pension Program would continue to function parallel to the National Pension Scheme, and the Korean public pension system would remain a single-tier separated system (see figure 1).

Reform measures are mainly about parametric changes, and changes are introduced in an incremental manner. These episodes of reform have shown the newly emerging deliberative pattern of policy process as ongoing, with the National Assembly basically honoring the social compromise made in the deliberative framework. It has manifested a critical change in terms of decision making. Compared to the 2000 
reform - in which the policy process was dominated by the government-a wider range of stakeholders was able to participate in the debate and be represented in the Committee on the Reform of the Civil Service Pension Program. In addition, in contrast to the 2006-2007 reform, the civil service unions were able to participate in the committee and make their voice heard. Thus, the third reform ended up as a success by taking direct stakeholders into the institutional mode of coordination and making compromises.

Nevertheless, it is very important to note that the government's ability to influence the policy process and consequently to carry through its agenda remained strong. This is because, in the deliberative process, the government played the role of convenor and facilitator of the forum. In the end, the policy output of the reform process was very close to what the government wanted. 4

\section{CONCLUDING REMARKS}

This paper has examined the reform of the Civil Service Pension Program to trace the changing pattern of policy processes in Korea, where the policy regime of the developmental state used to be strong. In order to test the hypotheses of the decline of government influence and the inability to achieve social compromise, this paper has examined the interactions of stakeholders at the micro level. It has analyzed three episodes of reform-2000, 2007, and 2009-paying attention to three dimensions of the policy process to capture the changing mode of the developmental state: first, the policy goals; second, the range of policy actors participating; and third, the institutional arrangements that facilitate the coordination and influence that each actor exerts over others in order to reach decisions.

This paper shows that there has been a clear change in the policy process of reform (see table 4 for summary). In particular, a more deliberative pattern geared toward consensus building has emerged. There is a clear contrast in policy processes between the Civil Service Pension Program reforms of 2000 and those of 2007 and 2009. The Committee on the Reform of the Civil Service Pension Program was established by

4. Some scholars hold a different view, arguing that the 2009 reform process was a kind of non-decision-making process in which the government selected an agenda and committee participants to suit its intentions. However, others insist that the agenda-setting process of the 2009 reform was based on an "outside initiative model" in that policy experts and civil service unions suggested reform proposals. Furthermore, policy alternatives were decided through negotiation with stakeholders, especially with civil service unions (Min, 2011). 
Table 4. Summary of the Discussion

\begin{tabular}{l|l|l|l}
\hline \multicolumn{1}{c|}{ Policy process } & \multicolumn{1}{|c|}{ 1st reform (2000) } & 2nd reform (2006-2007) & \multicolumn{1}{c}{ 3rd reform (2009) } \\
\hline Multiple policy goals & Emerging but limited & Emerging & Emerging \\
\hline Diverse policy actors & Emerging but limited & $\begin{array}{l}\text { Emerging to a limited } \\
\text { extent }\end{array}$ & $\begin{array}{l}\text { Emerging to a } \\
\text { significant extent }\end{array}$ \\
\hline $\begin{array}{l}\text { Deliberative mode of } \\
\text { coordination }\end{array}$ & Emerging but very limited & $\begin{array}{l}\text { Emerging but failed to } \\
\text { compromise }\end{array}$ & $\begin{array}{l}\text { Emerging, operating well, } \\
\text { and finally successful }\end{array}$ \\
\hline
\end{tabular}

the government as a deliberative arena, and different social actors were able to represent their interests in the discussion and make proposals, compromising on their differences. In the second reform episode, however, stakeholders failed to make compromises due to competing policy goals: controlling government expenditure and structural reform of the public pension systems. In the third episode of reform, compromise was finally achieved among stakeholders, including the government employee unions.

In conclusion, three trends can be identified. First, conflicting policy goals have emerged among government ministries, unlike in the policy process of the developmental state, in which the goal of economic growth was given first priority. Second, the old bureaucracy-led policy-making process of the developmental state has been replaced by a deliberative policy-making process that involves more actors-policy experts, unions, and various other stakeholders. Third, the institutional mode of coordination has evolved from a hierarchical arrangement toward a more deliberative mode involving persuasion and compromise.

This was not the first time in which an institutional setting for deliberation for social actors was built to promote social compromise. The tripartite committee established at the time of the Asian economic crisis turned out to be short-lived despite its initial success. The breakdown of mutual trust between the government and medical doctors with respect to health care reform in 2002 was another case for pessimism (Kwon \& Chen, 2007). Since then, there have been strong doubts as to whether these social consensus institutions would be functional in Korean politics. In this context, the policy process regarding civil service pension reform provides counter-evidence that social consensus can be arrived at in a deliberative way.

One of the paradoxes that has been witnessed in the three episodes of reform is that, while a new pattern of policy making is emerging, especially the inclusion of a range of social actors in deliberative institutions, the government's strategic influence in policy making continues to be strong. This is mainly because the government has the power to convene and set agendas for the deliberative process. It has been the government that has initiated and managed the deliberative process for reform. At the same time, it is true that the different ministries competed against each other to 
promote diverse policy goals.

Given the changes in the policy process, the pension reform introduced in the decade beginning in 2000 brought about essentially parametric changes. The reform is set to increase the level of contributions and reduce the level of pensions in order to consolidate the financing of the program. The government will still be required to provide financing in order to fill the deficit, although it will be a smaller amount than expected under the current system. In short, the public pension system in Korea will remain a single-tier separated system-which means that one of the core institutions of the developmental state will remain.

These observations lead to the more important question of the role of the state in the governance structure. At an earlier stage of governance study, the notion of "governance without government" was emphasized as the new trend (Peters \& Pierre, 1998; Rhodes, 1997). However, this paper shows that the state still plays a significant role in policy coordination, as seen in the three episodes of pension reform. The role of the state as convenor within the governance structure warrants further examination in a future study.

\section{REFERENCES}

Adelman, I. 1997. Social development in Korea, 1953-1993. In D. Cha, K. Kim, \& D. Perkins (eds.), The Korean economy 1945-1995. Seoul: Korea Development Institute.

Baccaro, L., \& Lim, S.-H. 2007. Social pacts as coalitions of the weak and moderate: Ireland, Italy and South Korea in comparative perspective. European Journal of Industrial Relations, 13(1): 27-46.

Choi, Y. J. 2008. Pension policy and politics in East Asia. Policy \& Politics, 36(1): 127-144.

Government Employees Pension Service. 2005. Statistics on civil service pensions. Seoul: Government Employees Pension Service (in Korean). . 2007. Statistics on civil service pensions. Seoul: Government Employees

Pension Service (in Korean).

Haggard, S. 1988. The politics of industrialization in East Asia and Taiwan. In H. Hughes (ed.), Achieving industrialization in East Asia. Cambridge: Cambridge University Press.

Hayasi, S. 2010. The developmental state in the era of globalization: Beyond the Northeast Asian model of political economy. The Pacific Review, 23(1): 45-69. Holliday, I. 2000. Productivist welfare capitalism: Social policy in East Asia. Political 
Studies, 48(4): 706-723.

James, E. 1997. Public pension plans in international perspective: Problems, reforms and research issues. In S. Valdes Prieto (ed.), The economics of pensions: Principles, policies, and international experience. Cambridge: Cambridge University Press.

Johnson, C. 1999. The developmental state: Odyssey of a concept. In M. Woo-Cumings (ed.), The developmental state. Ithaca, NY: Cornell University Press.

Kim, J. K, \& Kim, J. R. 2002. Estimation for the financial sustainability of the Civil Service Pension Program. Seoul: Government Employees Pension Service (in Korean).

Kim, S. 2005, November 11. We need urgently to reform the Civil Service Pension Program. Joongang Daily.

Kim, T.-I. 2004. Equity analysis of public employees' pension system through comparisons with the National Pension System. Korean Public Administration Review, 38(6):111-129 (in Korean).

Kingdon, J. W. 1984. Agendas, alternatives, and public policies. Boston: Little, Brown.

Kohli, A. 2004. State-directed development: Political power and industrialization in the global periphery. New York: Cambridge University Press.

Korea Development Institute. 1999. Policy alternatives for civil service pension reform. Seoul: Korea Development Institute (in Korean).

Kwon, H. J. 2003. The reform of the developmental welfare state in Korea: Advocacy coalitions and health politics. In UNRISD workshop on social policy in a development context. Bangkok.

Kwon, H. J., \& Chen, F.-L. 2007. Governing universal health insurance in Korea and Taiwan. International Journal of Social Welfare, 17(4): 355-364.

Kwon, H. J., \& Kwak, H. K. 2006. Reform of the Civil Service Pension Program and policy issues. Korean Policy Studies Review, 15(4): 189-213 (in Korean).

Lee, J. 2007. A study of national pension reform in Korea: Focusing on the introduction of individual accounts and decentralized decisions on asset portfolios. Regulation Studies, 16(1): 67-116 (in Korean).

Meny, Y. 1990. Government and politics in western Europe: Britain, France, Italy, West Germany and USA. Oxford: Oxford University Press.

Min, H. 2011. Why was the government employee pension's 2009 reform still a moderate reform? Korean Policy Studies Review, 20(1): 333-376 (in Korean).

Peters, B. G., \& Pierre, J. 1998. Governance without government? Rethinking public administration. Journal of Public Administration Research and Theory, 8(2): 223-243. 
Rhodes, R. A. W. 1997. Understanding governance: Policy networks, governance, reflexivity and accountability. Buckingham: Open University Press.

Ro, C. 1981. The remuneration system of the civil service and its morale. Review of the Korean Association of Public Administration, 15: 43-58.

Song, H.-K., \& Hong, K. 2006. The beginning of the welfare state: Democratization, globalization and Korean welfare politics. Paju: Nanam Publishing House.

Weiss, L. 2000. Developmental state in transition: Adapting, dismantling, innovating, not "normalizing." The Pacific Review, 13(1): 21-55.

Wong, J. 2005. Re-making the developmental state in Taiwan: The challenges of biotechnology. International Political Science Review, 26(2): 169-191.

Yoo, H. 1966. Social background of the Korean high-rank officials. Administrative Review, 4(2): 243-266 (in Korean). 